\title{
Detection of antibiotics residues in meat of reformed and marketed laying hens in southern Benin
}

\author{
S. E. P. MENSAH ${ }^{1 *}$, H. Y. AHISSOU ${ }^{2}$, O. D. KOUDANDE ${ }^{1}$, S. SALIFOU ${ }^{2}$, \\ G. A. MENSAH ${ }^{1}$ and F. A. ABIOLA ${ }^{2}$ \\ ${ }^{1}$ Institut National des Recherches Agricoles du Bénin, Centre de Recherches Agricoles d'Agonkanmey, \\ Laboratoire des Recherches Zootechnique, Vétérinaire et Halieutique (INRAB/CRA-Agonkanmey/LRZVH) \\ 01BP 884 Recette Principale Cotonou, Bénin. \\ ${ }^{2}$ Université d'Abomey-calavi, Benin. \\ *Corresponding author, E-mail: egidemensah@yahoo.fr
}

\begin{abstract}
The presence in meat products of antibiotic residues is of toxicological risks for the consumer. In order to protect consumers through the safety of meat from reformed and marketed laying hens, a qualitative study was conducted in southern Benin. The study was conducted in twenty laying hen farms in Abomey-Calavi, Ouidah and Porto Novo towns. The survey identified antibiotics used by farmers. In each farm, five reformed chickens ready to be marketed were randomly selected. On each bird, the sternum and right thigh were collected and analyzed by the microbiological method of four plates at the Laboratory. Results showed that farmers use eight families of antibiotics: aminoglycosides, diaminopyridines, macrolides, polypeptides, quinolones second and third generation, sulfonamides and tetracyclines. Residues of tetracyclines and aminoglycosides were found only in Abomey-Calavi town with respective proportions of $25.71 \pm 10.14 \%$ and $21.41 \pm 9.93 \%$ while residues of macrolides were observed in three localities which are Abomey- Calavi, Ouidah and Porto Novo, with respective rates of $65.71 \pm 9.92 \%, 46 \pm 15.5 \%$ and $20 \pm 8.36 \%$. From the above results, we recommend to veterinarians the efficient use of antibiotics and to poultry farmers the respect of withdrawal period.
\end{abstract}

(C) 2011 International Formulae Group. All rights reserved.

Keywords: Antibiotics residues, laying hens, sternum, thigh, Benin.

\section{INTRODUCTION}

Benin is one of the African countries classified as less developed. In these countries, statistics on the use of veterinary drugs in livestock are not available. The figures on quantities of antibiotics consumed in the animal production sector in Benin are not always accurate. In addition, no investigation for the presence of veterinary drug residues in meat products has been conducted. The presence of veterinary drug residues in meat products indicates the misuse of veterinary drugs, including the non observance of withdrawal period required before consumption of the treated animal (Abiola et al., 2005). This poses a problem of 
public health. Teh and Rigg 1992 reported that the presence of residues of penicillin in chicken produces severe anaphylactic reactions to consumers. Currently in Benin control of meat products in the context of food safety does apply to drug residues. However, these drug residues may compromise the safety of food and endanger the health of consumers (Bada-Alambedji et al., 2004). The aim of the study is to identify the different veterinary antibiotics used in livestock farming of laying hens and measure the amount of residues present in reformed laying hen's meat in southern Benin.

\section{MATERIALS AND METHODS}

Study area and sampling period

The study was conducted in southern Benin in Cotonou, Ouidah and Porto Novo localities. Samples were collected from late November to late December 2008 during the festive season when poultry products commercialized are important and this, by referring to census forms of modern poultry farmers (Dougnon, 2004).

\section{Nature of antibiotics used in farming of laying hens}

A questionnaire was used to collect informations from twenty chicken farms. Information on antibiotics used and diseases treated were collected.

\section{Sampling}

A total of twenty laying hens were sampled: eight in Porto Novo, five in Ouidah and seven in Abomey-Calavi. From each selected farm, five reformed laying hens ready for the market were randomly selected. Each hen was labeled and transported to the Laboratory of Microbiology Research on Veterinary Drugs Residues of Zootechnic, Veterinary and Fish Research Laboratory, located at Agonkanmey Agricultural Research Center (CRA-Agonkanmey) of the National Institute of Agricultural Research of Benin. On the carcass of each group, microbiological testing was performed on the sternum and the right leg thigh muscles. Each muscle was removed using a sharp knife. The various samples are collected and introduced in a sterilized pouch with identification number in their free end. The bag was then tied at its upper end with a node and stored at $-18{ }^{\circ} \mathrm{C}$.

\section{Materials for microbiological analysis}

Materials used were analytical strains: ATCC 6633 Bacillus subtillis agar pH 6 (BS6), pH 8 agar (BS 8) and Micrococcus luteus ATCC 9341 agar pH 8 (ML 8).

\section{Qualitative identification of antibiotic residues} The standard microbiological

method for the detection of residues, developed by a working group of the European Economic Community (EEC) in 1980, called "four plate" (Bogaerts and Wolf, 1980; AFSSA, 2003; Fabre et al., 2004) was used. The test is conducted by agar diffusion. Samples of chicken meat thawed previously placed in duplicate on the surface of four agars cast in Petri dishes and inoculated with reference strains : Bacillus subtilis ATTC 6633 (at $\mathrm{pH}$ 6,7.2 and 8) and Micrococcus luteus ATCC $9341 \quad$ (pH 8.0). Trimethoprim is incorporated into the medium at $\mathrm{pH} 7.2$ to increase the sensitivity of the test for sulfonamide residues. Interpretation of the results is to look for samples for which the growth of one (or both) microorganisms is inhibited in an annular zone at least $2 \mathrm{~mm}$ wide.

\section{Statistical analysis}

Data were processed using EXCEL and SAS (VO. 9.2). To compare proportions of muscles of different origin containing antibiotics residues, we performed the analysis of variance (ANOVA). The presence of the couple beta-lactam - macrolides antibiotics in the muscle was compared within each locality. For the analysis, the arcsinus of percentages were used. Means were compared by computing Student-Newman-Keuls' test, at 0.05 probability level. 


\section{RESULTS}

The antibiotics used in livestock farming of laying hens in South Benin

All of the twenty farms studied were specialized in table eggs production only. The average number of bird per farm is $1,000 \pm$. All of these farms use antibiotics for the control and treatment of various problem diseases. In general, the pathologies treated are salmonellosis, mycoplasmosis, colibacillosis, coccidiosis, pasteurellosis, chronic respiratory disease and stress. Indeed, poultry farmers in Porto Novo and Ouidah use more antibiotics than those of Abomey-Calavi (Figure1).

Most antibiotics used by farmers surveyed are administered orally to birds in drinking water or food. The antibiotics used by farmers are part of aminoglycosides, diaminopyridines, macrolides, polypeptides, second and third generations of quinolones, sulfonamides and tetracyclines drug families (Figure 2).

\section{Detection of antibiotic residues in meat of reformed laying hens}

Laboratory tests identified beta-lactam and tetracycline, aminoglycosides, betalactam and macrolides residues in meat (Table 1). Proportions of meat conta ning beta-lactam and tetracyclines residues ranged from 0 to $25.71 \%$ and those containing aminoglycosides residues are between 0 and $21.43 \%$. The highest proportions of meat containing betalactam - tetracyclines, and aminoglycosides residues $(\mathrm{p}<0.05)$ were observed in poultry flocks of Abomey-Calavi town. No significant difference $(p>0.05)$ was observed between proportions of meat containing residues of beta-lactam - tetracyclines and aminoglycosides sampled in Ouidah and Porto Novo. The proportion of meat containing beta-lactam and macrolides residues varied from 20 to $65.71 \%$. We noted a significant difference $(\mathrm{p}<0.05)$ between proportions of reformed chickens meat $(65.71 \%)$ containing beta-lactam and macrolides residues in reformed birds in Abomey-Calavi and those raised in Ouidah
(46\%) and Porto-Novo (20\%). This same difference is observed within the towns of Ouidah and Porto Novo. The table shows also that beta-lactam - tetracyclines and aminoglycosides antibiotics residues are observed only in reformed chicken's meat in Abomey-Calavi. Beta-lactam and macrolides residues are present in reformed chicken's meat of three localities surveyed.

\section{Presence of residues of beta-lactam and macrolides in sternum and thigh muscles}

The results of Table 2 shows that betalactam and macrolides residues are present in both sternum and thigh muscles of reformed chickens in farms of Abomey-Calavi and Porto-Novo. Beta-lactam and macrolides residues are not present in thigh muscles of reformed chickens in farms of Ouidah. The proportions of sternum muscles containing beta-lactam and macrolides residues ranged from 35 to $94.29 \%$ while thigh muscles range from 0 to $37.15 \%$. Statistical test indicated no significant difference $(p>0.05)$ between Abomey-Calavi and Ouidah farms. However, there is a significant difference $(\mathrm{p}<0.05)$ between reformed chickens of AbomeyCalavi, Ouidah and Porto-Novo farms. Likewise, there is a significant difference $(\mathrm{p}<$ 0.05 ) between thigh muscles of reformed chickens containing antibiotic residues in Abomey-Calavi and Ouidah farms and between chickens in Abomey-Calavi and Porto Novo. Similarly, a difference was noted between thigh muscles of chickens from poultry flocks located in Ouidah $(0 \%)$ and those of Porto-Novo (5\%). The percentage of sternum muscles of laying hens containing residues of beta-lactam and macrolides is significantly higher than that of thigh muscles $(\mathrm{p}<0.05)$.

\section{Presence of residues of beta-lactam and tetracyclines in sternum and thigh muscles}

Table 3 provides an overview of proportions of sternum and thigh muscles of reformed laying hens containing residues of beta-lactam and tetracyclines according to localities. It is clear from this table that 
sternum and thigh muscles positive of betalactam and tetracyclines residues have been observed only in the town of Abomey-Calavi in equal proportions.

\section{Presence of residues of aminoglycosides in} sternum and thigh muscles

Table 4 shows the percentage of sternum and thigh muscles of laying reformed containing residues of aminoglycosides following localities where poultry flocks are installed. The proportions of sternum muscles (25.71\%) positive for residues aminoglycosides are higher than those of thigh muscles $(17.14 \%)$. These positive cases were observed only in the town of AbomeyCalavi.

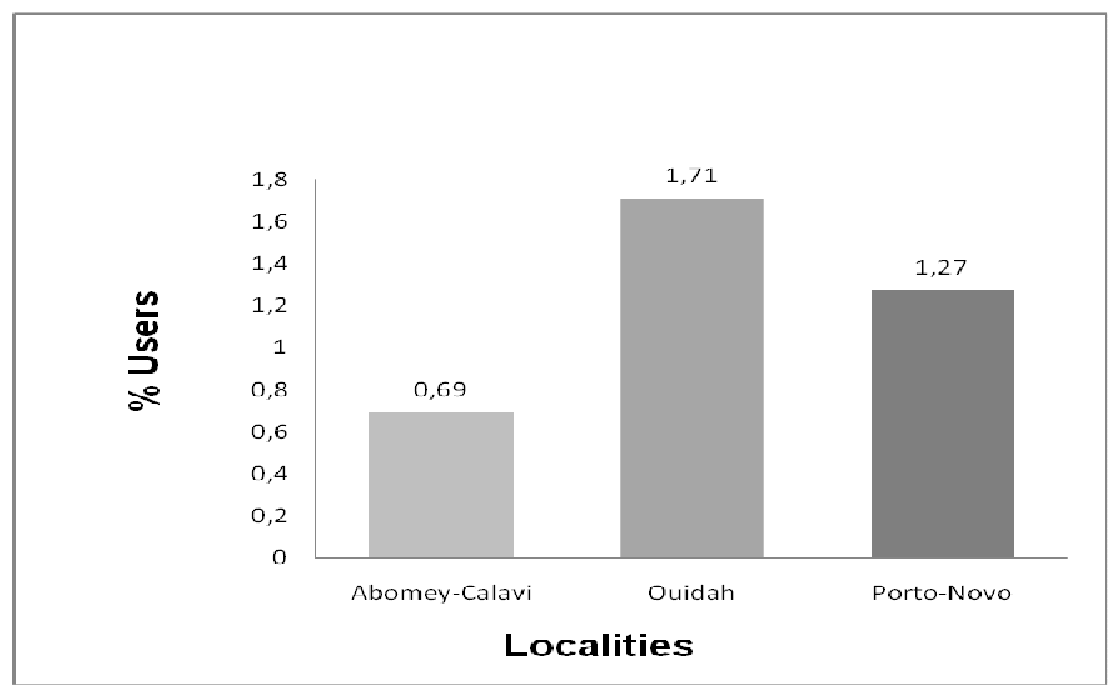

Figure 1: Importance of the use of antibiotics in localities studied.

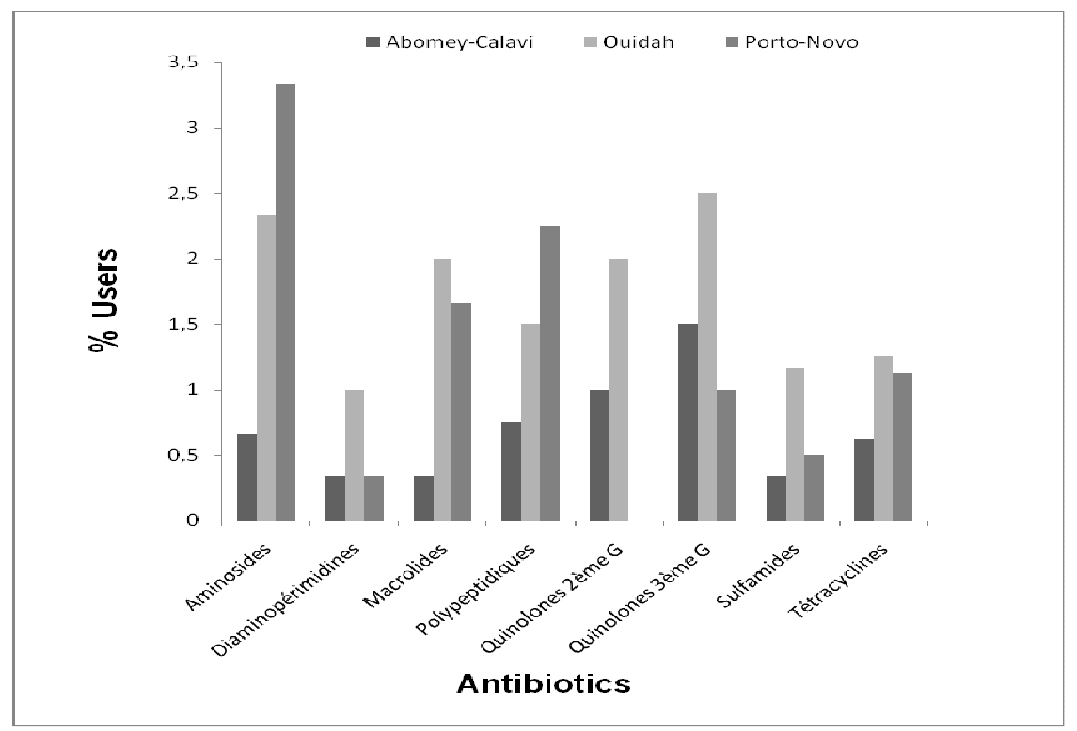

Figure 2: Importance of families of antibiotics used in the area of investigation. 
Table 1: Importance of meat of reformed chickens containing residues of antibiotics.

\begin{tabular}{lccc}
\hline Localities & \multicolumn{2}{c}{ Rate (\%) of meat containing antibiotic residues } \\
\cline { 2 - 4 } & $\begin{array}{c}\text { beta-lactam and } \\
\text { tetracyclines }\end{array}$ & aminoglycosides & $\begin{array}{c}\text { beta-lactam and } \\
\text { macrolides }\end{array}$ \\
\hline Abomey-Calavi & $25.71 \pm 10.14 \mathrm{a}$ & $21.43 \pm 9.93 \mathrm{a}$ & $65.71 \pm 9.92 \mathrm{a}$ \\
Ouidah & $0 \pm 0 \mathrm{~b}$ & $0 \pm 0 \mathrm{~b}$ & $46 \pm 15.5 \mathrm{~b}$ \\
Porto-Novo & $0 \pm 0 \mathrm{~b}$ & $0 \pm 0 \mathrm{~b}$ & $20 \pm 8.36 \mathrm{c}$ \\
\end{tabular}

Mean values not followed by the same letter in the same column are significantly different at $5 \%$ probability level.

Table 2: Proportion of poultry flocks whose meat contains residues of beta-lactam antibiotics and macrolides.

\begin{tabular}{|c|c|c|c|}
\hline \multirow[t]{2}{*}{ Localities } & \multicolumn{3}{|c|}{ Rate $(\%)$ of samples with residues of beta-lactam antibiotics and macrolides } \\
\hline & Sternum & Thigh & $\mathbf{P}$ \\
\hline Abomey-Calavi & $94.29 \pm 3.68$ a A & $37.15 \pm 11.89$ a B & 0.001 \\
\hline Ouidah & $92 \pm 4.89$ & $0 \pm 0 \quad \mathrm{~b} \mathrm{~B}$ & $<0.001$ \\
\hline Porto-Novo & $35 \pm 15$ & $5 \pm 3.27$ b B & 0.050 \\
\hline $\mathrm{P}$ & 0.004 & 0.003 & \\
\hline
\end{tabular}

The average values of the same line not followed by the same uppercase letter are significantly different at $5 \%$ probability level.

The average values of a column not followed by the same lowercase letter are significantly different at $5 \%$ probability level.

Table 3: Proportion (\%) of matrices hens reformed containing residues of beta-lactam antibiotics and tetracyclines.

\begin{tabular}{lcc}
\hline Localities & \multicolumn{2}{c}{ Matrices } \\
\cline { 2 - 3 } & Sternum & Thigh \\
\hline Abomey-Calavi & $25.71 \pm 14.93$ & $25.71 \pm 14.93$ \\
Ouidah & $0 \pm 0$ & $0 \pm 0$ \\
Porto-Novo & $0 \pm 0$ & $0 \pm 0$ \\
\hline
\end{tabular}

Table 4: Proportion (\%) matrices hens reformed containing residues of aminoglycosides.

\begin{tabular}{lcc}
\hline Localities & \multicolumn{2}{c}{ Matrices } \\
\cline { 2 - 3 } & Sternum & Thigh \\
\hline Abomey-Calavi & $25.71 \pm 14,93$ & $17.14 \pm 14.09$ \\
Ouidah & $0 \pm 0$ & $0 \pm 0$ \\
Porto-Novo & $0 \pm 0$ & $0 \pm 0$ \\
\hline
\end{tabular}




\section{DISCUSSION}

It appears in the results obtained from the studies that the only visit of keeping laying we conducted during this study certainly does not properly assess antibiotic residues presence in meat of reformed laying hens. Several visits spread over time enabled a better understanding of the problem, so far as negative cases could be obtained positive few weeks earlier and vice versa. Also, could it be that withdrawal period is exceeded for some samples. Furthermore, the scarce use logbook and treatment by farmers has deprived us from useful information on frequencies and duration of antibiotic use. That information led to a better understanding of the presence or the absence of antibiotic residues in meat of reformed laying hens when investigating. Finally, the combination of seed-culture medium (four plate method) can detect the following four families of antibiotics: betalactam and tetracyclines, sulfonamides and aminoglycosides beta-lactam and macrolides. But it is a method that is not specific because it reveals both presence of beta-lactam group and tetracyclines in boxes BS6 and betalactam and macrolides in ML8 boxes. It becomes difficult to speculate on the presence of a substance or another. However, this method has been applied without technique of detecting sulfonamides. This is because of non-availability on domestic and regional standard that is Sulfadimérazine marketed by the laboratory SIGMA (Germany).

\section{Use of antibiotics in livestock farming of laying hens}

Samples of this study were obtained from farms located in some localities of southern Benin where practice of laying hens is intensive. Types of antibiotics used by poultry farmers existing in localities surveyed are diverse. This diversity is similar to the results of Kabir et al. (2004) and Tatsadjieu Ngoune et al. (2009) who identified respectively among others in laying hens farms of Kaduna State in Nigeria and Cameroun, using oxytetracycline (OTC), Streptomycin, Tylosin and Amprolium furaltadone by poultry farmers. This could be explained by a variety of bacterial diseases rampant in farms or by an indiscriminate use of antibiotics by farmers. Field observations also showed that most poultry farmers treat bacterial infections indiscriminately without recourse to veterinarian and without prior antibiogram. This is justified by the fact that in Benin and Togo, methods of monitoring and inspection of veterinary drugs in supply chain are still missing (Biaou et al., 2002). Farms located in Abomey-Calavi use few varieties of antibiotics as the livestock farms located in Porto-Novo and Ouidah this could be explained either by non-reporting by some breeders of all antibiotics they use. This small variety of antibiotics used in Abomey-Calavi could also be justified by better coverage of that locality by veterinary practices (four) compared to Quidah (one) and Porto-Novo (two), which necessarily implies better monitoring in the use of antibiotics. In veterinary medicine, aminoglycosides are primarily used for Gram-negative septicemia as salmonellosis. They are also of broad spectrum antibiotics used to treat digestive and respiratory chicken's diseases (Villemin et al., 1984). Their use by many poultry farmers could be explained by predominance in their holdings of these diseases. Indeed, farms generally installed in urban or periurban areas where the most polluted atmosphere favor the onset of respiratory diseases. On the other hand, inputs used in feeding laying hens are often of questionable microbiological quality and poorly stored causing digestive disorders (Dossa et al., 2004). All poultry farmers administer various molecules orally. This practice is common in poultry flocks (Biagui, 2002).

\section{Presence of antibiotic residues in meat of reformed laying hens}

This work reveals for the first time the presence of beta-lactam and tetracyclines, aminoglycosides and of beta-lactam and macrolides residues in muscles of sternum and thigh of reformed laying hens marketed in 
southern Benin. It confirms the results of Bada-Alambedji et al. (2004) in Dakar. Our results corroborate also those of authors like Roudaut (1997); Châtaigner and Stevens (2003) who have shown that mass administration of antibiotics in chickens entail most often the presence of residues in tissues and foods by these animals. The absence of residues of tetracyclines and aminoglycosides in farms located at Ouidah and Porto Novo at the time of the survey does not mean a strict observance of withdrawal periods after using antibiotic; in farms. This absence fairly allows us say that the last use of antibiotics on chickens concerned was in a long time sufficient for elimination of these products. The presence of high residues can be explained by a lower level of education of farmers in these localities who would misunderstand the importance of the timeout. OTC is a drug widely used in the breeding of laying hens to combat respiratory and digestive illnesses. Proportions of $25.71 \%$ obtained in this study are higher than the $16.67 \%$ obtained in Dakar by Châtaigner and Stevens (2003) and slightly lower than the $26.77 \%$ reported by N'Kaya (2004) also in Dakar. Few studies reported severe adverse reactions to the consumption of OTC. According to Anthony (1977), excessive bowel gas diagnosed in consumers can be attributed to the consumption of residues of OTC products through meat. There is also fear as for the development of Franconi Syndrome following exposure to tetracyclines residues. This has not been reported as a result of residues but described in some genetically predisposed individuals to degradation of tetracycline (Gross, 1963). However, experts from WHO Commission for residues have recommended a maximum rate of OTC residues in meat and eggs which must be respectively 100 and $200 \mathrm{ug} / \mathrm{kg}$ (WHO, 1996). The percentage of meat containing residues of aminoglycosides $(21.43 \%)$ obtained in this study is higher than that found $(8.33 \%)$ by Châtaigner and Stevens in 2003 and the one of $(7.87 \%)$ reported by N'Kaya (2004) in Dakar. Relatively the higher rates (20 to $65.71 \%$ ) of meat positive residues compared with macrolides tetracyclines ( 0 to $25.71 \%$ ) and aminoglycosides (0 to $21.43 \%$ ) in three localities could be explained by the extensive use of this family of antibiotics during the month of December (survey period) against the occurrence of respiratory illness in poultry flocks. The rates of $20-65 \%$ achieved following our investigations are consistent with those found by Châtaigner $(62.5 \%)$ in 2003 and N'Kaya (77\%) in Dakar. The main complication observed following the use of macrolides in animals is a gastrointestinal disorder. For humans exposed to a long-term consumption of products containing residues of macrolides, we observe diarrhea and vomiting sensations (Clark, 2008).

\section{Presence of macrolide residues in sternum and thigh muscles}

The presence of macrolide residues in muscle of sternum and thigh of reformed laying hens was due to the phenomenon of diffusion of drug in the body. When the drug is administered, it is absorbed, distributed, metabolized and excreted. During distribution, the passage of drug occurs in different tissues of the body through bloodstream unevenly (Roudaut, 1997). The high rate (35 to $94.29 \%$ ) of infected sternum registered compared to that of thigh ( 5 to $37.15 \%$ ) of reformed laying hens could be explained in several ways. According to Clark (2008), macrolides by their lipophilicity and bases have a low intracellular distribution and focus within cells. Inside the cell and given physical and chemical conditions in intracellular environment, they are ionized and can no longer escape by diffusion due to non-soluble ionized state. They are thus trapped and their concentration is increasing in tissues. Sternum muscle is a white muscle that has less fat, mitochondria and smooth endoplasmic 
reticulum (SER) which the hamstring is a red muscle. However, smooth endoplasmic reticulum plays an essential role in detoxification. The elimination of toxic substances is by a conjugation process that makes them more soluble and occurs primarily in liver and other organs. It takes place during two stages. During the first stage, the toxic substance can be hydrolyzed, reduced, oxidized or hydroxylated. Hydroxylation is very frequent and depends on cytochrome P 450; an intrinsic membrane protein of SER associated with a complex carrier of electrons. During the second stage, the toxic molecule undergoes a conjugation reaction with glucuronic acid given by uridine diphosphate glucuronic acid or with sulfuric acid made in the form of 3'-phosphoadenosine-5 'phosphosulfate, with either glycine, etc. These enzymatic reactions will aim at making toxic substance soluble in order to eliminate it. Toxic molecules are translocated into cavity of the SER, where they are processed into a soluble non-toxic molecule therefore easily removable in thigh at the level of the sternum (Maillet, 2006).

\section{Presence of residues of tetracyclines in thigh and sternum muscles}

The same percentage $(25.71 \%)$ of sternum and thigh muscles containing tetracyclines residues observed could be explained by physicochemical characteristics of tetracyclines. Indeed, tetracyclines have a high tissue binding and intracellular thereby fight infection in many organs as lung, liver and kidneys. Work already done on this antibiotic family indicates that they are more soluble, what would explain their concentration in tissues (Roudaut, 1997). They also have an affinity with vascular tissue rich in calcium (Hinz et al., 1972).

\section{Presence of residues of aminoglycosides in sternum and thigh muscles}

The presence of aminoglycosides in sternum and thigh muscles is justified because of their solubility. The percentage difference observed between sternums and thighs contaminated with aminoglycosides is explained by the fact that aminoglycosides are antibiotics in plasma and extracellular localization. The dissemination of aminoglycosides in tissues is very limited because of the nature of ionized intracellular low. The difference in drug concentration in tissues is related to their kinetics in vessels. Better, this kinetics depends on the caliber of vessels supplying muscles N'Kaya (2004). In general, high rates of reformed chickens muscle marketed contaminated with antibiotic residues indicate a high use of antibiotics. Normally, chickens are raised with drugs so that they reach a maximum body weight in a short time. Birds treated with these drugs produce eggs containing residues after withdrawal period (Donoghue et al., 1996). The failure to observe withdrawal period by poultry farmers in Benin is the reason of the presence of residues in target tissues. Also, this practice would help it to develop resistance and multiple resistant bacteria causing serious consequences to public health (EU Scientific Steering used solely as, 1999 and Wolfgang, 1998).

\section{Conclusion}

The study showed that farmers use at least eight antibiotics families' aminoglycosides, diaminopyridines, macrolides, polypeptide, quinolones second and third generation, sulfonamides and tetracyclines. Also meat of reformed chickens sold in southern Benin at time of study contained residues of tetracyclines, aminoglycosides and macrolides. These results reflect misuse of antibiotics in poultry flocks sampled. This result is an increased risk of bacterial antibiotic selection in humans. This requires a study on national level with a larger sample and farmers sensitization regarding rational use of antibiotics in their livestock. 


\section{REFERENCES}

Abiola AF, Diop MM, Teko-Agbo A, Délépine B, Biaou FC, Roudaut B, Gaudin V, Sanders P. 2005. Résidus d'antibactériens dans le foie et le gésier de poulets de chair dans les régions de Dakar et de Thiès (Sénégal). Revue Méd. Vét., 156(5) : 264-268.

AFSSA (Agence Française de Sécurité Sanitaire des Aliments). 2003. Détection des résidus à activité antibiotique dans le muscle: Méthode des quatre boîtes. Protocole d'exécution. LMV/90/01Version 4. 11.

Bada-Alambedji R, Cardinal E, Biagui C, Akakpo AJ. 2004. Recherche de résidus de substances à activité antibactérienne dans la chair de poulet consommée dans la région de Dakar (Sénégal). Bull. Acad. Vét. France, 157(2) : 67-70.

Biagui C. 2002. Utilisation des médicaments vétérinaires en élevage avicole dans la région de Dakar; qualité de la viande à travers la recherche de résidus de substances à activité antimicrobienne (Antibiotiques). Thèse de Doctorat en Médecine Vétérinaire, Ecole Inter-Etats des Sciences et Médecine Vétérinaires, Université Cheick Anta Diop de Dakar, p. 153.

Biaou CF, Teko-Agbo A, Faure P, Abiola AF. 2002. Le marché des médicaments vétérinaires en Afrique de l'Ouest: Particularités et réglementation. Animalis, 1(3): 34-38.

Bogaerts R, Wolf f. 1980. A standardized method for detection of residues of antibacterial substances in fresh meat. Fleischwirtschaft, (60): 672-673.

Châtaigner B, Stevens A. 2003. Investigation sur la présence de résidus d'antibiotiques dans les viandes commercialisées à Dakar. Rapport de recherche; p. 66.

Clark RC. 2008. Investigation of the potential use, pharmacokinetics and safety of Tilmicosin Horses. Thèse de Doctorat, Département des Sciences Biomédicale et
Vétérinaire, Université de SaskatchewanSaskatoon, p. 253.

Donoghue DJ, Hairston H, Gaines SA, Bartholomew MJ, Donoghue AM. 1996. Modeling residue uptake by eggs. Similar drug residue patterns in developing yolks following injection with ampicillin or oxytetracycline. Poultry Science, (75): 321-328.

Dossa CS, Fandohan P, Gbéou U, MENSAH S, da Gbadji R. 2004. Qualité des aliments composites des monogastriques produits dans le Sud et Centre du Bénin. Rapport technique de Recherche. INRAB/CRA-A/LRZVH. P. 28.

Dougnon TJ. 2004. Profils immunologiques des pathologies infectieuses dominantes des poulets d'élevage importés dans le Sud-Bénin. Mémoire de DEA, Faculté des Sciences, Université de Lomé Togo, p. 98.

EU Scientific Steering Committee. 1999. Opinion of the European Union Scientific Steering Committee on Antimicrobial Resistance, (http://europa.eu.int/comm/ food/fs/sc/ssc/out50_en.html).

Fabre JM, Microvich C, Geijp E, Moretain JP, Beneteau E, Martineau GP. 2004. Résidus d'antibiotiques dans la viande de porc et de volaille en France : situation actuelle et évaluation d'un nouveau test de détection. Bulletin des GTV., (23): 305309.

Gross JM. 1963. Fanconi syndrome (Adult type) developing secondary to ingestion of outdated tetracycline. Annals of Internal Medicine, (58): 523-528.

Hinz KH, Lai KW, Lubers H. 1972. Lichttaglänge und oxytetracyclinBlutplasmaspiegel bei Legehennen nach. Verabreichung von Oxytetracyclin in therapeutischer Dosierung über das Futter. Zentralblatt Fuer Veterinaermedizin, Reihe B., (19): 99110.

Kabir J, Umoh VJ, Audu-okoh E, Umoh JU, Kwaga JKP. 2004. Veterinary drug use in 
poultry farms and determination of antimicrobial drug residues in commercial eggs and slaughtered chicken in Kaduna State, Nigeria. Food Control, (15): 99-105.

Maillet M. 2006. Abrégés de Biologie Cellulaire (10 ${ }^{\mathrm{ème}}$ édition). Masson.

N'Kaya T. 2004. Etude comparative de la présence des résidus d'antibiotiques dans les muscles de la cuisse et du bréchet du poulet de chair dans la région de Dakar. Thèse de Médecine Vétérinaire, Ecole Inter-Etats des Sciences et Médecines Vétérinaires, Université Cheick Anta Diop de Dakar, p. 115.

Roudaut B. 1997. Antibiothérapie chez la poule pondeuse : Etude des résidus d'Antibiotiques dans les œufs. Thèse de Doctorat de l'Institut National Polytechnique de Toulouse, p. 179.

Tatsadjieu Ngoume L, Tanedjieu KS, Mbofung CMF. 2009. Impact de l'utilisation des antibiotiques sur la sensibilité des bactéries pathogènes de poules dans la ville de Ngaoundéré. Cameroun Journal of Expérimental Biology, 5(2): 52-61.

Teh WL, Rigg AS. 1992. Possible penicillin allergy after eating chicken. Lancet, ii, 1632.

Villemin P, Brugere H, Brugere-Picoux J. 1984. Le traitement des infections respiratoires des volailles. Rec. Méd., (160): 1117-1128.

WHO. 1996. Evaluation of certain veterinary drug residues in food. Fourty fifth report of the Joint FAO/WHO Expert Committee on Food Additives. WHO Technical Report Series, (864): Geneva.

Wolfgang W. 1998. Medical consequences of antibiotic use in agriculture. Science, (279) : 996-997. 